\title{
Strategi Komunikasi Pemasaran Catering Zella dalam Mempertahankan Loyalitas Pelanggan Selama COVID-19
}

\author{
Arvin Stephensius ${ }^{1}$, Septia Winduwati ${ }^{2 *}$ \\ ${ }^{1}$ Fakultas Ilmu Komunikasi, Universitas Tarumanagara, Jakarta \\ Email: Arvin.915160166@stu.untar.ac.id \\ ${ }^{2}$ Fakultas Ilmu Komunikasi, Universitas Tarumanagara, Jakarta* \\ Email: septiaw@fikom.untar.ac.id
}

Masuk tanggal : 15-12-2021, revisi tanggal :06-01-2022, diterima untuk diterbitkan tanggal : 16-01-2022

\begin{abstract}
Catering Zella is one of the MSMEs which is engaged in the food business. This UMKM has become one of the popular caterers in Bekasi City. However, since the COVID-19 virus entered Indonesia and the stipulation of the PSBB by the government, Catering Zella has experienced a decline in turnover. But Catering Zella was able to survive. The success in surviving these difficult times cannot be separated from the communication strategy adopted by Catering Zella. By using qualitative research types and case study research methods, the author wants to describe how the communication strategy adopted by Catering Zella in maintaining customer loyalty during the COVID-19 pandemic. The purpose of this study was to determine the marketing communication strategy in maintaining customer loyalty of Catering Zella during the COVID-19 pandemic. The theories used in this research are marketing communication strategy theory, UMKM, and customer loyalty. The data analyzed were the results of interviews with a permanent lecturer at the Faculty of Communication Sciences at Tarumanagara University, literature studies related to communication strategies and customer loyalty, as well as a review of documents related to Zella Catering. The results of this study indicate that Catering Zella is able to maintain customer loyalty through a marketing communication strategy
\end{abstract}

Keywords: COVID-19, customer loyalty, marketing communication strategy

\begin{abstract}
Abstrak
Catering Zella merupakan salah satu UMKM yang bergerak dalam bidang usaha makanan. UMKM ini menjadi salah satu catering yang diminati di Kota Bekasi. Namun, sejak virus COVID-19 masuk ke Indonesia dan ditetapkannya PSBB oleh pemerintah, Catering Zella mengalami penurunan omset. Namun Catering Zella mampu bertahan. Kesuksesan untuk bertahan di masa-masa sulit ini tentu tidak lepas dari strategi komunikasi yang diterapkan oleh Catering Zella. Dengan menggunakan jenis penelitian kualitatif dan metode penelitian studi kasus, penulis ingin menguraikan bagaimana strategi komunikasi yang diterapkan oleh Catering Zella dalam mempertahankan loyalitas pelanggan selama pandemi COVID-19. Tujuan penelitian ini adalah untuk mengetahui strategi komununikasi pemasaran dalam mempertahankan loyalitas pelanggan Catering Zella selama pandemi COVID-19. Teori-teori yang digunakan dalam penelitian ini adalah teori strategi komunikasi pemasaran, UMKM, dan loyalitas pelanggan. Data yang dianalisis merupakan hasil wawancara dengan satu dosen tetap Fakultas Ilmu Komunikasi Universitas Tarumanagara, studi kepustakaan yang berkaitan dengan strategi komunikasi dan loyalitas pelanggan, serta telaah dokumen yang berkaitan dengan Catering Zella. Hasil penelitian ini menunjukkan bahwa Catering Zella mampu mempertahankan loyalitas pelanggannya melalui strategi komunikasi pemasaran
\end{abstract}

Kata Kunci: COVID-19, loyalitas pelanggan, strategi komunikasi pemasaran 


\section{Pendahuluan}

Virus COVID-19 sedang melanda dunia dan menginfeksi umat manusia. World Health Organization (WHO) menetapkan ini sebagai pandemi yang melanda seluruh dunia. Indonesia pun menjadi salah satu negara yang terkena dampaknya. Menurut Taher (2020), sejak 10 April 2020 Jakarta menjadi kota pertama yang menerapkan Pembatasan Sosial Berskala Besar (PSBB). Ini pun diikuti oleh beberapa kota kota lain di Indonesia.

Dampak negatif yang ditimbulkan oleh Virus Corona ini ada pada berbagai sektor, diantaranya adalah sektor ekonomi. Berdasarkan informasi yang disajikan oleh Fadila (2020), sekitar 163.713 pelaku Usaha Mikro Kecil dan Menengah (UMKM) terkena dampak pandemi, salah satunya adalah Catering Zella.

Catering Zella merupakan salah satu UMKM yang bergerak dalam bidang usaha makanan, didirikan oleh Sri Yusi Prihatini. UMKM yang sudah berdiri sejak tahun 2002 ini berlokasi di Perumahan Pesona Anggrek Harapan Blok A10 No 19, Bekasi Utara, Harapan Jaya Kota Bekasi.

Berdasarkan hasil studi pendahuluan, Catering Zella merupakan salah satu catering yang cukup diminati di kota Bekasi sehingga Catering Zella ini seringkali mendapatkan orderan dalam jumlah besar setiap harinya. Menurut Sri Yusi Prihatini, pemilik Catering Zella, sejak pandemi COVID-19, Catering Zella mengalami penurunan omset yang cukup signifikan. Meskipun begitu, Catering Zella tidak benarbenar kehilangan pelanggan tetapnya. Hingga kini, Catering Zella masih memiliki 30 pelanggan yang tetap dan tidak pernah absen untuk memesan catering di Catering Zella. Keloyalan pelanggan di Catering Zella ini tentu tidak terlepas dari penerapan strategi komunikasi pemasaran.

Menurut Soemanagara (Kusniadji, 2016), strategi komunikasi pemasaran diartikan menjadi kegiatan pemasaran dengan menggunakan teknik-teknik komunikasi yang ditujukan untuk memberi informasi kepada khalayak agar tujuan perusahaan tercapai, yaitu perusahaan mengalami peningkatan pendapatan sebagai output penambahan penggunaan jasa atau pembelian produk yang ditawarkan.

Strategi yang disusun harus bergantung pada situasi dan kondisi. Strategi komunikasi pemasaran berperan sangat penting bagi pelaku usaha/bisnis. Tanpa strategi komunikasi pemasaran, khalayak yang menjadi konsumen secara keseluruhan tidak akan mengetahui keberadaan produk di pasar.

Menurut Kennedy dan Soemanagara (Fatihudin dan Firmansyah, 2019) ada lima strategi komunikasi dalam pemasaran, antara lain iklan (Advertising), promosi penjualan (Sales Promotion), hubungan masyarakat (Public Relations), penjualan personal (Personal Selling), penjualan langsung (Direct Selling).

Kemudian, Agus (2012) menambahkan beberapa jenis strategi komunikasi pemasaran lainnya, antara lain sponsorship, corporate identity, packaging, poin of sale and merchandising, dan word of Mouth. Adapun dalam penerapannya, strategi komunikasi memiliki beberapa langkah (Veni, 2018), antara lain menetapkan sasaran/khalayak, membuat pesan, menetapkan metode komunikasi, memilih sarana komunikasi yang ingin digunakan.

Selama pandemi pelaku usaha dipaksakan untuk bisa mendapatkan loyalitas pelanggan. Griffin (Fian dan Yuniati, 2016) mengungkapkan loyalitas pelanggan adalah komitmen pelanggan terhadap suatu brand, atau pemasok berdasarkan sikap yang sangat positif dan tergambarkan melalui pembelian ulang yang konsisten. Untuk 
mendapat loyalitas pelanggan, pemilik usaha harus memberikan perhatiannya kepada kepuasan pelanggan terhadap produk tau jasa yang diberikan.

Menurut Kotler (Nayaakyasa, 2015), loyalitas bisa dilihat melalui kesetiaan pelanggan untuk membeli produk, ketahanan terhadap pengaruh yang negatif mengenai produk dan jasa, serta merekomendasikannya ke kerabat. Sedangkan, halhal yang dapat membentuk dan mempertahankan loyalitas pelanggan adalah penawaran yang menggugah interest pembeli, mendidik pembeli tentang apa yang dibutuhkan, dan memberi penghargaan kepada pembeli (Widodo, 2017).

Catering Zella sendiri merupakan salah satu catering yang tetap dapat mempertahankan eksistensinya pada saat pandemi ini. Meskipun sedang terjadi pandemi, saat ini, pelanggan tetap yang selalu memesan catering di Catering Zella cukup banyak, yaitu berjumlah 30 pelanggan belum lagi ditambah dengan pesananpesanan nasi box yang selalu diterima setiap minggunya.

Hal ini menunjukkan bahwa adanya loyalitas dari pelanggan terhadap Catering Zella. Oleh karena hal tersebut penulis tertarik untuk mengulas lebih lanjut tentang Catering Zella dengan judul "Strategi Komunikasi PemasaranCatering Zella Dalam Mempertahankan Loyalitas Pelanggan Selama Pandemi COVID-19". Adapun tujuan dari penelitian ini adalah mengetahui strategi komunikasi pemasaran Catering Zella dalam mempertahankan loyalitas pelanggannya selama pandemi COVID-19.

\section{Metode Penelitian}

Dalam penelitian ini, penulis menggunakan pendekatan kualitatif. Sedangkan, metode penelitian yang digunakan adalah studi kasus. Dalam penelitian ini, penulis mengumpulkan data melalui tiga cara, yaitu wawancara terstruktur dengan tiga narasumber dari Catering Zella sebagai studi pendahuluan dan satu dosen tetap Fakultas Ilmu Komunikasi Universitas Tarumanagara sebagai narasumber utama, studi kepustakaan, dan dokumentasi. Sedangkan, teknik analisis data dalam penelitian ini melalui pengumpulan data, reduksi data, penyajian data, dan menarik kesimpulan (Miles dan Huberman dalam Sugiyono, 2020). Untuk menguji keabsahan data, penulis melakukan triangulasi (Sugiyono, 2020).

\section{Hasil Temuan dan Diskusi}

Catering Zella merupakan salah satu catering yang berdomisili di Bekasi, Jawa Barat. Catering Zella didirikan Ibu Sri Yusi Prihatini sejak tahun 2002. Catering Zella berlokasi di Perumahan Pesona Anggrek Harapan Blok A10 No 19, Bekasi Utara, Harapan Jaya Kota Bekasi. Nama Catering Zella diangkat dari nama anak kelima Ibu Sri Yusi Prihatini, yang merupakan satu-satunya anak perempuan Ibu Sri.

Catering Zella berawal dari tahun 2002 di mana Ibu Sri seringkali mengantar makan siang ke sekolah untuk salah satu anak laki-lakinya. Meskipun di sekolah sudah disediakan catering makan siang untuk setiap anak, tetapi anak laki-lakinya tidak mau makan makanan catering tersebut dengan alasan kurang makanannya kurang sedap. Kemudian, beberapa orang tua murid yang mengetahui hal tersebut, datang dan menghampiri Ibu Sri untuk menawarkan Ibu Sri juga membuatkan menu makanan untuk anak-anak mereka. Menurut penuturan beberapa orang tua murid tersebut, hidangan menu yang dibuat oleh Ibu Sri cukup baik dan memenuhi standar makanan empat sehat lima sempurna. 
Semakin hari semakin banyak orang tua yang turut meminta Ibu Sri membuatkan catering untuk makan siang anak-anaknya di sekolah hingga pada akhirnya total langganan Ibu Sri berjumlah 150 orang. Sejak saat itu, Ibu Sri memutuskan untuk membuat catering yang diberi nama Catering Zella.

Meskipun Catering Zella merupakan catering rumahan, tetapi Catering Zella sudah menerima banyak pesanan dalam jumlah yang cukup besar. Beberapa di antaranya, pada tahun 2004, Catering Zella di minta suatu perusahaan besar untuk mengisi catering karyawan sebanyak 350 orang setiap harinya selama lima tahun. Selain itu, Catering Zella juga pernah menerima pesanan katering di sekolah SMPIT Al-Muchtar hingga 2009 lalu berlanjut menerima pesanan katering pernikahan, ulang tahun hingga saat ini

\section{Loyalitas Pelanggan Catering Zella}

Salah satu strategi pemasaran ialah dengan jalan membangun dan meningkatkan loyalitas pelanggan untuk selalu membeli produk yang dijual. Loyalitas pelanggan diartikan sebagai keinginan dari konsumen untuk membeli dan menggunakan suatu produk secara berkala dan secara suka rela merekomendasikan produk perusahaan tersebut kepada para kerabatnya.

Menurut Tjiptono (dalam Kurniasih, 2012), loyalitas adalah komitmen untuk bertahan secara mendalam dengan melakukan pembelian ulang atau berlangganan kembali dengan produk atau jasa yang diminati secara konsisten dimasa yang akan datang. Mengacu pada hasil wawancara dan uraian teori di atas, terhitung sebanyak 30 pelanggan Catering Zella selalu melakukan repeat purchase selama tiga hari setiap minggunya.

Hal ini menunjukkan bahwa pelanggan melakukan pembelian ulang secara teratur. Selanjutnya, indikator retention. Meskipun dalam keadaan pandemi yang berpengaruh terutama pada sektor ekonomi, pelanggan Catering Zella tidak terpengaruh untuk berhenti memesan katering di Catering Zella.

Menurut analisis yang telah dilakukan penulis, hal di atas terjadi karena harga menu makanan yang disajikan relatif murah dikalangan pelanggannya, serta kualitas makanan yang disajikan Catering Zella juga cukup enak. Kemudian, indikator ketiga untuk mengukur loyalitas pelanggan pada suatu brand atau produk adalah referalls.

Berdasarkan hasil wawancara yang telah dilakukan, penulis menemukan bahwa beberapa pelanggan Catering Zella mengetahui Catering Zella dari kerabatnya yang telah melakukan pesanan terlebih dahulu di Catering Zella. Hal ini menunjukan adanya suatu referensi dari satu pelanggan ke pelanggan lainnya.

Loyalitas pelanggan merupakan salah satu hal terpenting bagi para pelaku bisnis karena membantu angka penjualan produk suatu perusahaan menjadi lebih baik dan mendapatkan keuntungan yang lebih tinggi. Oleh karena itu, pelaku bisnis disarankan untuk tidak mengabaikan nilai dan keuntungan tersembunyi di balik loyalitas pelanggan. Adapun cara yang dapat dilakukan pelaku bisnis untuk membangun loyalitas pelanggannya dengan menyediakan produk yang berkualitas.

Hasil penelitian ini mendukung penelitian yang dilakukan oleh Murwani (dalam Sonatasia, Onsardi, dan Arini, 2019) yang meneliti variabel kualitas produk terhadap loyalitas pelanggan, menunjukkan adanya pengaruh kualitas produk terhadap loyalitas pelanggan dengan kepuasan pelanggan.

Hal ini sejalan dengan upaya yang dilakukan oleh Catering Zella untuk selalu mempertahankan kualitas cita rasa dan kebersihan dapur maupun kedai selama 
mengerjakan hidangan-hidangan menu, memberikan pelayanan yang maksimal, serta memberikan potongan harga dan bonus extra makanan.

Selain itu, dalam membangun loyalitas pelanggan, perusahaan besar maupun industri kecil perlu memperhatikan pihak-pihak yang terlibat. Setiap bagian suatu perusahaan turut berperan dan memiliki perannya masing-masing dalam membentuk dan mempertahankan loyalitas pelanggannya. Hal ini sejalan dengan penelitian yang dilakukan Afifah dan Evelina (2012), bahwa dalam mempertahankan loyalitas pelanggan sebaiknya tidak hanya diterapkan oleh divisi marketing saja.

Menurut Sahir dan kawan-kawan (2020), kemampuan manajerial diartikan sebagai segala potensi dan keahlian yang digunakan pengelola usaha untuk mengatur, mengkoordinasikan, dan menggerakkan para bawahan ke arah tujuan yang telah ditentukan oleh perusahaan. Pada Catering Zella, pengelola usaha belum mengoptimalkan kemampuan manajerial ini, terutama dalam melakukan promosi produk. Ketiga media sosial ini dikelola oleh pemilik Catering Zella sehingga penggunaannya kurang maksimal.

Berdasarkan hasil studi pendahuluan, hal di atas terjadi karena pemilik Catering Zella tidak memiliki waktu yang cukup untuk mengelola media sosial yang ada dan pemilik Catering Zella juga merangkap sebagai pemegang pembukuan keuangan yang utama.

\section{Strategi Komunikasi Pemasaran Catering Zella}

Menurut Ramadhani (2020), Usaha Mikro, Kecil, dan Menengah (UMKM), dapat digambarkan sebagai usaha yang digerakan oleh individu, rumah tangga, atau badan usaha ukuran kecil. Primiana (dalam Ramadhani, 2020) mendeskripsikan UMKM sebagai aktivitas bisnis dalam skala kecil yang mendukung pergerakan pembangunan serta perekonomian Indonesia.

UMKM terdiri dari tiga jenis bentuk usaha, yaitu mikro, kecil, menengah. Catering Zella merupakan salah satu bisnis UMKM golongan usaha kecil karena memiliki ciri-ciri dengan pemasukan sekitar 240 juta per tahun dan merupakan usaha informal dalam bidang kuliner (Ramdhani, 2020).

Catering Zella sebagai pelaku UMKM tentunya memiliki strategi komunikasi yang telah ditetapkan untuk meningkatan penjualan produk kateringnya, meningkatkan brand awareness konsumen terhadap Catering Zella, serta mempertahankan loyalitas pelanggannya.

Meskipun begitu, tidak semua perusahaan mampu untuk mengoptimalkan strategi komunikasi pemasarannya agar produk/jasa yang diproduksi dikenal oleh masyarakat. Hal ini kebanyakan terjadi dikalangan perusahaan kecil, seperti UMKM.

Hal ini sejalan dengan pernyataan Munawar, Juningsih, dan Maulana (2016), tidak semua UMKM mampu mengoptimalkan strategi komunikasi pemasaran. Dari berbagai jenis strategi komunikasi pemasaran, yang paling banyak digunakan oleh perusahaan besar biasanya dalam bentuk advertising. Namun, ini merupakan kekurangan bagi UMKM di mana menggunakan iklan di media massa tentunya sangat menguras biaya.

Selain itu, dalam hal public relations, UMKM belum dapat memanfaatkannya karena konsentrasi SDM yang ada sebagian besar atau bahkan seluruhnya sudah terfokus pada pekerjaannya masing-masing yang hanya berkaitan dengan produk hingga penjualannya. Hal ini berkaitan dengan penemuan penulis pada Catering Zella, di mana Catering Zella belum mampu mengoptimalkan advertising di media massa dan public relations sebagai strategi komunikasi pemasaran karena karyawannya yang 
minim dan sudah terfokus pada pekerjaannya yang hanya berkaitan dengan katering. Meskipun begitu, Catering Zella telah menerapkan jenis strategi komunikasi pemasaran lainnya yang lebih sederhana, seperti word of mouth dan personal selling.

Selanjutnya, berdasarkan hasil studi pendahuluan dan analisis penulis, ditemukan bahwa Catering Zella telah menerapkan langkah-langkah strategi komunikasi dalam mempertahankan loyalitas pelanggannya. Strategi komunikasi memilki langkah-langkah yang harus diperhatikan agar tujuan komunikasi dapat sukses tercapai. Menurut Anwar (dalam Veni, 2018) langkah-langkah strategi komunikasi adalah mengenal sasaran/khalayak, menyusun pesan untuk membangkitkan perhatian, menetapkan metode dalam komunikasi (beberapa metode di antaranya adalah redundancy, canalizing, informatif, persuasif, edukatif), serta pemilihan sarana komunikasi yang tepat.

Pada langkah pertama strategi komunikasi, Catering Zella telah menentukan target sasarannya, yaitu masyarakat kelas menengah ke bawah. Menurut Catering Zella, masyarakat kelas menengah ke bawah merupakan target yang cocok dengn menu hidangan yang disajikan Catering Zella. Kemudian, langkah kedua strategi komunikasi pemasaran, yaitu Catering Zella selalu memposting testimoni foto-foto makanan yang pernah dipesan pelanggan sebelumnya sebagai ajang promosi. Selain itu, Catering Zella turut menyampaikan pesan sekaligus promosi mengenai produknya melalui e-brosur. E-brosur disusun dengan isi tema menerima pesanan dan materi yang singkat, padat, dan jelas.

Langkah strategi komunikasi ketiga adalah menentukan metode komunikasi yang tepat. Menurut Arifin (dalam Veni, 2018), metode penyampaian dapat dilihat dari dua aspek, yaitu menurut cara pelaksanaannya (metode redundancy /repetition dan metode canalizing) dan menurut bentuk isinya (metode informatif, metode persuasif, metode edukatif). Metode komunikasi yang diterapkan oleh Catering Zella adalah metode redundancy, di mana Catering Zella intens dan secara berulang mempromosikan menu hidangannya melalui postingan di status whatsapp, instagram, dan facebook

Selain iu, Catering Zella juga mempromosikan kateringnya dengan cara menyampaikan informasi yang berisi keterangan fakta-fakta mengenai Catering Zella, seperti menu hidangan, harga dan diskon, dan alamat. Menurut Arifin (dalam Veni 2018), cara ini disebut juga sebagai metode informatif dan persuasif dalam strategi komunikasi.

Langkah strategi komunikasi yang keempat adalah pemilihan sarana komunikasi yang tepat. Dalam hal ini, Catering Zella menggunakan media internet sebagai sarana komunikasi. Media internet yang paling diunggulkan oleh Catering Zella adalah whatsapp, facebook, instagram, dan situs web. Akan tetapi, facebook dan instagram belum digunakan secara maksimal dikarenakan Catering Zella tidak memiliki karyawan yang khusus untuk menangani publicity Catering Zella.

Namun, meskipun Catering Zella menggunakan media internet sebagai sarana komunikasi, tetapi media internet bukan yang utama. Menurut Catering Zella, komunikasi secara langsung dan promosi dari mulut ke mulut merupakan strategi komunikasi terbaik. Seperti yang telah dijelaskan sebelumnya, jika dikaitkan dengan teori strategi komunikasi pemasaran menurut Kotler dan Keller (2012), strategi promosi dari mulut ke mulut yang diterapkan oleh Catering Zella ini dinamakan sebagai strategi word of mouth (WOM).

Menurut Kotler dan Keller (2012), promosi dari mulut ke mulut atau yang biasa disebut Word of Mouth (WOM) merupakan proses komunikasi yang berupa pemberian 
rekomendasi, baik secara individu maupun kelompok terhadap suatu produk atau jasa yang bertujuan untuk memberikan informasi secara personal.

Menurut Hasan (2010), Word of Mouth (WOM) memberikan manfaat di mana informasi yang disampaikan lebih independen dan jujur, menghasilkan media iklan informal, tidak dibatasi ruang dan waktu, serta memberikan pengalaman langsung kepada yang bertanya tentang produk melalui pengalaman teman dan kerabat.

Selain strategi Word of Mouth (WOM), strategi komunikasi pemasaran lain yang dilakukan oleh Catering Zella adalah personal selling. Personal selling atau penjualan langsung menurut Kotler dan Keller (2012) dapat menjadi strategi komunikasi pemasaran dimana pihak pemilik usaha berinteraksi langsung dengan pelanggannya. Dalam hal ini, pelaku usaha dapat menjelaskan produknya lebih detail dan menerima feedback dari pelanggan. Pada Catering Zella, personal selling tentunya dilakukan oleh Ibu Sri sebagai pemilik Catering Zella.

Sesuai dengan konsep teorinya, Ibu Sri berusaha selalu berinteraksi langsung dengan pelanggannya untuk memberikan penjelasan mengenai hidangan menu yang disajikan serta selalu menerima feedback dari pelanggan, terutama kekurangan dari hidangan menu yang disajikan Catering Zella sehingga nantinya dapat diperbaiki.

\section{Simpulan}

Berdasarkan hasil penelitian di atas, maka penulis dapat memberikan kesimpulan sebagai berikut :

a. Catering Zella mampu mempertahankan loyalitas pelanggannya, terutama saat pandemi COVID-19. Hal ini terlihat dari adanya pembelian katering secara berkala oleh pelanggan Catering Zella dan adanya suatu referensi dari satu pelanggan ke pelanggan lainnya.

b. Loyalitas pelanggan merupakan salah satu hal yang sangat penting bagi setiap pelaku usaha. Keuntungan yang akan diperoleh perusahaan apabila memiliki konsumen yang loyal, antara lain membantu menghemat biaya pengeluaran, dapat meningkatkan penjualan dan keuntungan bisnis, mendorong getok tular (word of mouth).

c. Dalam membentuk dan mempertahankan loyalitas pelanggan, setiap bagian atau divisi dari sebuah perusahaan harus memberikan kontribusi, tidak hanya berpaku pada divisi marketing saja.

d. Catering Zella telah menerapkan strategi komunikasi untuk mempertahankan loyalitas pelanggannya. Adapun strategi komunikasi yang diterapkan Catering Zella dalam mempertahankan loyalitas pelanggan, yaitu menggunakan strategi komunikasi pemasaran personal selling dan word of mouth.

e. Fokus sasaran konsumen Catering Zella adalah masyarakat kelas menengah ke bawah yang memiliki kebutuhan katering dengan harga relatif murah, seperti yang disediakan oleh Catering Zella.

f. Catering Zella membuat pesan sebagai strategi komunikasi melalui e-brosur dan hasil dokumentasi pesanan-pesanan yang pernah diterima oleh Catering Zella.

g. Metode komunikasi yang diterapkan oleh Catering Zella, antara lain metode redundancy, informative, dan persuasive.

h. Sarana komunikasi yang dipilih oleh Catering Zella adalah media internet, seperti facebook, whatsapp, instagram, dan situs web. Akan tetapi, Catering 
Zella lebih memilih melakukan promosi lewat komunikasi langsung dengan pelanggan.

i. Upaya yang dilakukan Catering Zella dalam mempertahankan loyalitas pelanggannya selama pandemi ini adalah selalu mempertahankan kualitas cita rasa dan kebersihan dapur maupun kedai

\section{Ucapan Terima Kasih}

Peneliti ingin mengucapkan terima kasih kepada Fakultas Ilmu Komunikasi Universitas Tarumanagara, narasumber, serta semua pihak yang turut membantu peneliti sehingga penelitian ini dapat diselesaikan.

\section{Daftar Pustaka}

Afifah, N. S. \& Evelina, L. W. (2012). Skripsi Strategi Public Relations dalam Membangun Customer Relationship Management Di PT. Sungwon Button Indonesia Periode April 2012. Jakarta

Fian, J. A. \& Yuniati, T. (2016). Artikel Pengaruh kepuasan dan kepercayaan pelanggan terhadap loyalitas pelanggan Auto 2000 Sungkono: Jurnal Ilmu dan Riset Manajemen, Vol. 5, No. 6. Surabaya

Firmansyah, Y., \& Oktaviani, F. (2018). Strategi komunikasi komunitas pungklung dalam membangun citra positif di masyarakat. JURNAL SIGNAL, Vol. 6, No. 2. Cirebon.

Kurniasih, I. D. (2012). Pengaruh harga dan kualitas pelayanan terhadap loyalitas pelanggan melalui variabel kepuasan (Studi pada Bengkel Ahass 0002- Astra Motor Siliwangi Semarang). Jurnal Administrasi Bisnis, Vol. 1, No.1.

Kusniadji, S. (2016). Strategi Komunikasi Pemasaran Dalam Kegiatan Pemasaran Produk Consumer Goods (Studi Kasus Pada PT Expand Berlian Mulia Di Semarang): Jurnal Komunikasi, Vol. 8, No.1

Munawar, S. S., Juningsih, E. R., \& Maulana, S. (2016). Peran Komunikasi Pemasaran dalam Sudut Pandang UMKM: Pembelajaran untuk Pemberdayaan UMKM. Proceeding Seminar Nasional Peningkatan Kapabilitas UMKM dalam Mewujudkan UMKM Naik Kelas

Nayaakyasa. (2015). Loyalitas Pelanggan https://nayaakyasazilvi.wordpress.com/2014/07/11/loyalitas-pelanggan/ diakses pada tanggal 24 November 2020

Ramadhani, N. (2020). UMKM Pengertian dan Perannya dalam Ekonomi https://www.akseleran.co.id/blog/umkm-adalah/ diakses pada tanggal 25 Desember 2020

Sahir, S. H., dkk. (2020). Keterampilan Manajerial Efektif. Medan: Yayasan Kita Menulis

Sonatasia, D., Onsardi, \& Arini, E. (2019). Strategi Meningkatkan Loyalitas Konsumen Makanan Khas Kota Curup Kabupaten Rejang Lebong. Prodi Manajemen Universitas Muhammadiyah Bengkulu

Tjiptono, F. (2016). Pemasaran Esensi dan Aplikasi. Yogyakarta: ANDI.

Widodo, W. (2017). Kualitas pelayanan terhadap kepuasan konsumen pada CV. Anugerah Sentosa di Pontianak: Jurnal Bisnis Manajemen, Vol. 1, No. 12. 